University of Nebraska - Lincoln

DigitalCommons@University of Nebraska - Lincoln

MANTER: Journal of Parasite Biodiversity

Parasitology, Harold W. Manter Laboratory of

9-15-2015

\title{
Metazoan Endoparasites of the Gray Fox, Urocyon cinereoargenteus from New Mexico
}

John E. Ubelaker

Southern Methodist University, ubelaker@smu.edu

Bretton S. Griffin

Southern Methodist University

Genevieve M. Konicke

Southern Methodist University

Nora Abdullah

Southern Methodist University

Aya Mouhaffel

Southern Methodist University

See next page for additional authors

Follow this and additional works at: https://digitalcommons.unl.edu/manter

Part of the Biodiversity Commons, Parasitology Commons, and the Zoology Commons

Ubelaker, John E.; Griffin, Bretton S.; Konicke, Genevieve M.; Abdullah, Nora; Mouhaffel, Aya; Duszynski, Donald; and Harrison, Robert L., "Metazoan Endoparasites of the Gray Fox, Urocyon cinereoargenteus from New Mexico" (2015). MANTER: Journal of Parasite Biodiversity. 1.

https://digitalcommons.unl.edu/manter/1

This Article is brought to you for free and open access by the Parasitology, Harold W. Manter Laboratory of at DigitalCommons@University of Nebraska - Lincoln. It has been accepted for inclusion in MANTER: Journal of Parasite Biodiversity by an authorized administrator of DigitalCommons@University of Nebraska - Lincoln. 


\section{Authors}

John E. Ubelaker, Bretton S. Griffin, Genevieve M. Konicke, Nora Abdullah, Aya Mouhaffel, Donald

Duszynski, and Robert L. Harrison 


\title{
Metazoan Endoparasites of the Gray Fox, Urocyon cinereoargenteus from New Mexico
}

\author{
John E. Ubelaker, ${ }^{1}$ Bretton S. Griffin, ${ }^{1}$ Genevieve M. Konicke, ${ }^{1}$ Nora Abdullah, ${ }^{1}$ \\ Aya Mouhaffel, ${ }^{1}$ Donald Duszynski, ${ }^{2}$ and Robert L. Harrison ${ }^{2}$
}

1 Department of Biological Science, Southern Methodist University, Dallas Texas, 75275

2 Department of Biology, University of New Mexico, Albuquerque, New Mexico 87131

Corresponding author - J. E. Ubelaker, email ubelaker@smu.edu

\begin{abstract}
Metazoan gastrointestinal endoparasites were recovered from 10 of 14 (71.4\%) gray foxes [Urocyon cinereoargenteus (Schreber, 1775)] collected in New Mexico from 1996 -1998. They include a pentastome Porocephalus sp., $(n=1,7.1 \%)$, a trematode: Fasciola hepatica Linnaeus, $1758(n=1,7.1 \%)$, the nematodes: Physaloptera rara Hall and Wigdor, $1918(n=3,14.3 \%)$, Physaloptera praeputialis Linstow, 1899 $(n=2,14.3 \%)$, an unidentified female Physaloptera sp. $(n=1,7.1 \%)$, Toxocara mystax (Zeder, 1800) $(n=2$, 14.3\%), Toxocara canis (Werner, 1782) $(n=1,7.1 \%)$, Spirocerca lupi (Rudolphi, 1809) $(n=6,42.9 \%)$, and cestodes: Taenia pisiformis (Bloch, 1780) n=3, n=3, (21.4\%), Taenia serialis (Gervais, 1847) $(n=3,21.4 \%)$, and Mesocestoides kirbyi Chandler, 1944 ( $n=7,50 \%)$. All parasites found are new records for the gray fox in New Mexico. The parasites, Porocephalus sp, Fasciola hepatica, Toxocara mystax and Mesocestoides kirbyi are new records for the gray fox for North America.
\end{abstract}

Keywords: Gray fox, Urocyon cinereoargenteus, New Mexico, Porocephalus sp. Fasciola hepatica, Physaloptera rara, Physaloptera praeputialis, Toxocara mystax, Toxocara canis, Spirocerca lupi, Taenia pisiformis, Taenia serialis, Mesocestoides kirbyi, Spirocerca lupi

The gray fox, Urocyon cinereoargenteus (Schreber, 1775) has a wide-ranging distribution in the Nearctic (Hall and Kelson, 1959) and occurs throughout New Mexico in woodland and rocky habitats (Findley et al., 1975). Fourteen gray foxes were collected in New Mexico from 1996 -1998 as part of an effort by the New Mexico Department of Game and Fish (NMDGF) to document the distribution of foxes in the state. Records of the fleas from these same animals were published by Harrison et al. (2003). Prior to the current paper, there have been no other reports of metazoan endoparasites of the gray fox in New Mexico. We report here on the metazoan endoparasites collected in gray foxes as part of this survey.

\section{Materials and Methods}

Most of the foxes were obtained from road-kills, but a few were shot or poisoned with M-44 by the Wildlife Services, Animal and Plant Health Inspection Service, US Dept. of Agriculture. Foxes were placed in plastic bags and frozen until they could be examined in the laboratory. The gastrointestinal tract, heart, and trachea were opened and the contents examined and endoparasites were picked from dissected animals. Helminths and a pentastome were preserved for study in $70 \%$ ethanol. Nematodes were later cleared and studied in glycerine or warmed lactophenol and then returned to the preservative. Cestodes were stained in carmine and mounted 
in Canada balsam for identification. The trematode and pentastome were examined in alcohol preparations. All foxes collected during this study are deposited in the Division of Mammals in the Museum of Southwestern $\mathrm{Bi}$ ology (MSB) The University of New Mexico, (UNM) Albuquerque, New Mexico, U.S.A. The host and parasite specimens are available for examination upon written request to the UNM MSB Division of Mammals. Voucher specimens were deposited in the Manter Laboratory Parasite Collection as follows: Fasciola hepatica (Linnaeus, 1758) [HWML66665], the pentastome, the cestode Mesocestoides kirbyi Chandler, 1944 [HWML49501] and the nematode Toxocara mystax Zeder 1800 [HWML66666] are deposited in the parasite collection of the Harold W. Manter Laboratory of Parasitology (UNSM), University of Nebraska State Museum, Lincoln, Nebraska.

\section{Results}

Ten of the 14 foxes (79\%) contained parasites. Four female foxes without parasites (21.4\%) were collected from Otero, Santa Fe and Lea counties. A pentastome, a trematode, three species of cestodes, and five species of nematodes were recovered at time of necropsy of the foxes (Table 1).

\section{Pentastomes}

A single specimen of the crustacean Porocephalus Humboldt, 1811 was found in a single fox collected from
Guadalupe County. Species of Porocephalus are parasites of snakes and $P$. crotali is present in rattlesnakes in North America (Riley, 1981). Esslinger (1962) experimentally demonstrated the life-cycle and used white mice as intermediate hosts. When rodents that are infected with pentastome nymphs are eaten by Crotalus spp. the nymphs are released from the rodent in the digestive system, penetrate the intestine, and mature in the lungs feeding on tissue fluids and blood. Layne (1967) reported rodents infected with nymphs in Florida and listed: Peromyscus floridanus (Chapman, 1889) (0.6\%), P. gossypinus (Le Conte, 1853) (4.3\%) and Sigmodon hispidus (0.2\%). Riley (1981) also reported pentastomes in western Diamonback rattlesnakes (Crotalus atrox Barid and Girard, 1853) The presence of a single adult pentastome in the intestine found in our study suggests that the fox preyed upon a rattlesnake and the adult pentastome was ingested with the meal or a nymph was obtained when a rodent was eaten. This is the first record of a pentastome in the gray fox.

\section{Trematodes}

One specimen of Fasciola hepatica Linneaus, 1758 (HWML66665) was collected from a single female fox in San Juan County. This trematode is an important parasite of domesticated livestock but has been reported from other mammals including rodents, rabbits, pigs, deer, dogs and other carnivores (Ulmer, 1975). Olson (1948) found that wild rabbits served as reservoir hosts of $F$.

Table 1. Parasites $(\bullet)$ recovered from each gray fox (Urocyon cineroargenteus) collected within New Mexico are categorized by the host's collection number, sex, and the county from which the host was collected. Parasites include: Fasciola hepatica, Pentasome sp., Mescestoides kirbyi, Taenia pisiformis, Taenia serialis, Spirocerca lupi, Toxocara canis, Toxocara cati, Physaloptera praeputialis, Physaloptera rara, and Physaloptera sp.

\begin{tabular}{|c|c|c|c|c|c|c|c|c|c|c|c|c|c|}
\hline Fox \# & Sex & County & $\begin{array}{c}F . \\
\text { hepatica }\end{array}$ & $\begin{array}{l}\text { Penta- } \\
\text { some }\end{array}$ & $\begin{array}{c}\text { M. } \\
\text { kirbyi }\end{array}$ & $\begin{array}{l}\text { T. pisi- } \\
\text { formis }\end{array}$ & $\begin{array}{c}T . \\
\text { serialis }\end{array}$ & $\begin{array}{l}\text { S. } \\
\text { lupi }\end{array}$ & $\begin{array}{c}T . \\
\text { canis }\end{array}$ & $\begin{array}{c}T . \\
\text { cati }\end{array}$ & $\begin{array}{l}\text { P. prae- } \\
\text { putialis }\end{array}$ & $\begin{array}{c}P . \\
\text { rara }\end{array}$ & $\begin{array}{l}P . \\
\mathrm{sp}\end{array}$ \\
\hline 6166 & $\mathrm{~F}$ & Lea & & & & & & & & & & & \\
\hline 6174 & $M$ & Lea & & & $\bullet$ & & & & $\bullet$ & & & $\bullet$ & \\
\hline 6182 & $\mathrm{~F}$ & Harding & & & $\bullet$ & $\bullet$ & $\bullet$ & $\bullet$ & & $\bullet$ & $\bullet$ & $\bullet$ & \\
\hline 6204 & $\mathrm{~F}$ & Lea & & & • & & $\bullet$ & - & & & & & \\
\hline 6205 & $M$ & Mora & & & & & & & & & & & • \\
\hline 6206 & $M$ & Otero & & & & & & & & & & & \\
\hline 6221 & M & Quay & & & $\bullet$ & & $\bullet$ & $\bullet$ & & & & & \\
\hline 6222 & M & Santa Fe & & & & & & & & & & & \\
\hline 6223 & $\mathrm{~F}$ & Santa Fe & & & & & & & & & & & \\
\hline 6225 & $\mathrm{~F}$ & San Juan & $\bullet$ & & $\bullet$ & $\bullet$ & & $\bullet$ & & & & & \\
\hline 6226 & $\mathrm{~F}$ & San Juan & & & $\bullet$ & $\bullet$ & & & & & & & \\
\hline 6227 & $\mathrm{~F}$ & Colfax & & & & & & $\bullet$ & & & & & \\
\hline 6238 & $\mathrm{M}$ & Catron & & & & & & $\bullet$ & & & & & \\
\hline 6239 & M & Guadalupe & & $\bullet$ & $\bullet$ & & & & & $\bullet$ & $\bullet$ & & \\
\hline
\end{tabular}


hepatica in southern Texas. Since only a single trematode was present in the intestine it seems likely that it was obtained from a recent meal. This is the first report of this trematode in the gray fox.

Other trematodes from the gray fox include Alaria americana (Walton, 1949) from southern Illinois by Dyer and Klimstra (1982) and from South Carolina by Davidson et al. (1992); Alaria canis La Rue and Fallis, 1934 from Minnesota by Erickson (1944); Alaria marcianae (La Rue, 1917) from Florida by Conti (1984) and Forrester (1992); Alaria arisaemoides Agustine and Uribe 1927; Alaria intermedia (Oliver and Odlaug, 1938) from Massachusetts by Rankin (1946); Paragonimus kellicotti Ward, 1908 from West Virginia by Davidson et al. (1992a); A. canis, Procyotrema marsupiformis Harkema and Miller, 1959, Eurytrema procyonis Denton, 1942, and E. vulpis Stunkard, 1947 from North Carolina, and Euryhelmis squamula (Rudolphi, 1819), E. vulpis, and Sellacotyle mustelae Wallace 1935 from Georgia by Miller and Harkema (1968), and $E$. procyonis from both southern Illinois by Dyer and Klimstra (1982a) and Maryland by Herman et al. (1957).

\section{Tapeworms}

Adult strobilae of Taenia pisiformis (Bloch, 1780) were recovered from three foxes (21.4\%), a female from Harding County ( 2 scolexes), and two females from San Juan County, each with a single scolex. Taenia serialis Gervais, 1847 was also recovered from three foxes, $(21.4 \%)$, including a female from Harding County (4 scolexes), a female from Lea County ( 1 scolex), and a male from Quay County (only proglottids). Hall (1920) reported T. pisiformis from gray foxes. Stiles and Baker (1935) reported Diphyllobothrium (possibly D. latum), and Taenia (possibly T. pisiformis) from the gray fox. Both tapeworm species were reported from gray foxes in Texas by Buechner (1944) who found that T. pisiformis was the most common tapeworm encountered with $56.7 \%$ of animals infected but $T$. serialis was not common, with only $5.5 \%$ of animals examined harboring this species. Miller and Harkema (1968) reported Taenia pisiformis, from grey foxes from North Carolina, South Carolina, and Georgia. Erickson (1944) reported Multiceps serialis (Gervais, 1847)from gray foxes in Minnesota. Hall (1919) reported T. pisiformis from a gray fox. MacGregor (1942) reported Taenia (possibly pisiformis) and an unidentified Taenia sp. from gray foxes in Massachusetts. Rankin (1946) found T. pisiformis in a single gray fox from Massachusetts. Erickson (1944) reported T. pisiformis (58\%) and a Taenia sp. from gray foxes in Minnesota. Dyer and Klimstra (1982) report T. pisiformis as the most common parasite in gray foxes from Southern Illinois. Conti (1984) reported T. pisiformis in $4 \%$ of gray foxes from Florida. He also found two other Taenia spp., one of which resembled T. macrocystis (Diesing, 1850) see also Forrester (1992). Ward (1947) found 15 of 17 (88\%) of gray foxes from Mississippi infected with T. pisiformis. Davidson et al. (1992) found Taenia crassiceps and Taenia pisiformis in South Carolina. Buechner (1944) examined 80 gray foxes from Harrison Co., eastern Texas and Kerr and Mason counties from central Texas. He reported the tapeworms Taenia pisiformis, and Taenia serialis. Erickson (1944) reported a Taenia sp. in $12.9 \%$ of gray foxes from Minnesota. The life cycle of $T$. pisiformis involves various species of hares, Lepus spp. and rabbits Sylvilagus spp.

In the current study, Mesocestoides kirbyi Chandler, 1944 was the most common tapeworm obtained. It occurred in 7 foxes (50\%) collected in Lea county (male with 1 scolex; female with 4 scolexes), Harding county (female with 245 scolexes), Quay county (male with 5 scolexes), San Juan county (female with 76 scolexes and a second female with 209 scolexes), and Guadalupe county, in a male that harbored 15 scolexes. The specimens of Mesocestoides observed here closely resemble M. kirbyi Chandler, 1944 from Canis latrans Say, 1823 in California that has bell-shaped gravid segments. The bell-shaped segments in our specimens average $1.36 \mathrm{~mm}$ wide and 1.9 $\mathrm{mm}$ long from the edges of the bell and $0.90 \mathrm{~mm}$ long from the posterior indention to the next proglottid. The parauterine organ is round, averaging 0.68 in diameter with an egg mass average of $0.24 \mathrm{~mm}$ in diameter. Shults (1970) reported M. kirbyi as a parasite of coyotes, Canis latrans, red foxes Vulpes vulpes (Linnaeus, 1758) wolverine, Gulo gulo (Linnaeus, 1758), and the lynx, Lynx canadensis Kerr, 1792 in Alaska and tetrathyridia were found in a red-backed vole, Clethrionomys rutilus (Pallas, 1779) also from Alaska. Based on field-based collections of $M$. lineatus and experimental infections of M. kirbyi, Shults (1970) redescribed and illustrated both species.

Buechner (1944) reported Mesocestoides litteratus (Batsch, 1786) in the gray fox in Texas. Mueller (1927) described Mesocestoides variabilis Mueller 1927 from Urocyon cinereoargenteus californicus Mearns, 1897 from California. Voge (1953) reported Mesocestoides variabilis in gray foxes from California and reported a tapeworm resembling M. manteri Chandler (1942) from Urocyon littoralis (Baird, 1858) from Santa Barbara, California. She reported tetrathyridia of $M$. variabilis from various lizards and snakes from California. Miller and Harkema (1968) reported M. variabilis from gray foxes from North Carolina, South Carolina and Georgia. Mesocestoides jonesi Ciordia, 1955 was described from a gray fox in Tennessee by Ciordia (1955). Mesocestoides variabilis was 
reported to occur in small percentages of gray foxes in southern Illinois by Dyer and Klimstra (1982). Buechner (1944) examined 80 gray foxes from Harrison Co. in eastern Texas and Kerr and Mason counties from central Texas and reported the tapeworm M. litteratus. Conti (1984) reported Mesocestoides sp. in gray foxes from Florida, see also Forrester (1992). Chandler (1942) reported on a human infection of Mesocestoides. Chandler (1942) described M. manteri from a Lynx. Voge (1953) considered that M. manteri to be a dwarf form of M. variabilis. Miller and Harkema (1968) and Dyer and Klimstra (1982) all consider that the epithet variabilis should be retained for all these species (ie. they should be synonyms of $M$. variabilis. The terminal gravid proglottids of M. variabilis are rectangular and not bell-shaped. On the basis of the bell-shaped terminal proglottids, the measurements of the egg mass and the paruterine organ, we refer our specimens to $M$. kirbyi which is a new record in the gray fox although, it has been reported from other foxes, including Alopex lagopus ILinnaeus, 1758), Vulpes vulpes, V. v. fulva (Desmarest, 1820), V. corsac (Linnaeus, 1768) as listed by Schmidt (1986). Mesocestoides litteratus and M. variabilis were listed by Erickson (1944) as parasites of the gray fox. Conti (1984) reported Mesocestoides sp. from Florida. Ubelaker et al (2013) reported M. variabilis from the red fox $V$. vulpes from New Mexico. Ubelaker et al. (2014) reported M. variabilis from kit foxes $V$. macrotis and Ubelaker et al. (2014a) found it in swift foxes V. velox (Say, 1823) in New Mexico.

Other records of tapeworms in gray foxes include Oochoristica mephitis Skinker 1935 and Dipylidium caninum (Linnaeus, 1758) from Massachusetts by Rankin (1946). Diphyllobothrium sp. (latum) by Stiles and Baker (1935), and Erickson (1944). Multiceps packii Christensen, 1929 was reported from Minnesota by Erickson (1944). Miller and Harkema (1968) reported spargana of Spirometra mansonoides Mueller, 1935 from gray foxes in North Carolina, South Carolina, and Georgia. Finally, Conti (1984) reported S. mansonoides from gray foxes in Florida, see also Forrester (1992).

\section{Nematodes}

\section{Genus Physaloptera Rudolphi 1819}

Physaloptera rara Hall and Wigdor, 1918 (14.3\%) was recovered from the stomach and small intestine of a male fox from Lee County (2 specimens) and in a female fox from Harding County (2 specimens). Morgan (1941) reported $P$. rara from a gray fox in Florida. Erickson (1944) found it in 34.2\% of gray foxes in Minnesota. Dyer and Klimstra (1982) reported $P$. rara in gray foxes in southern
Illinois. Conti (1984) found P. rara in 69\% of gray foxes in Florida. Buechner (1944) reported P. rara in 43 of 112 grey foxes (38.4\%) from central Texas but it was absent in foxes from east Texas. Forrester (1992) reported it from Florida. Ubelaker et al. (2014) found it in $43.4 \%$ of kit foxes (V. macrotis) and Ubelaker et al. (2014a) found it in $35.5 \%$ of swift foxes ( $V$. velox) from New Mexico.

Physaloptera praeputialis Linstow, 1899 was recovered from a single female fox from Harding County (1 specimen) and from a single male fox from Guadalupe County (5 specimens). A female Physaloptera sp. was recovered in a male from Mora County. Chitwood (1931) reported P. praeputialis from the gray fox in Virginia (see also Morgan (1941), Erickson (1944). Rankin (1946) reported a Physaloptera sp. in gray foxes from Massachusetts and Erickson (1944) in Minnesota. Davidson et al. (1992) recovered Physaloptera sp. in gray foxes from South Carolina but Erickson (1944) suggests that this identification is incorrect. Miller and Harkema (1968) reported the nematode Physaloptera maxillaris Molin 1860 from gray foxes from North Carolina, South Carolina, and Georgia.

\section{Genera Toxocara Stiles 1905 and Toxascaris Leiper, 1907}

Toxocara canis (Werner, 1782) was recovered from the intestine of a male fox in Lea County (4 specimens). Erickson (1944) reported $T$. canis as a parasite of gray foxes. Toxocara canis was reported in 1 of 2 gray foxes from Massachusetts by Rankin (1946). Toxocara canis and Toxascaris leonina (Linstow, 1902) were both reported from gray foxes by Dyer and Klimstra (1982) from southern Illinois, and Ward (1947) reported T. canis from 2 of 17 (12\%) gray foxes from Mississippi. Davidson et al. (1992) reported Toxascaris sp. and Toxocara sp. in gray foxes from South Carolina. Toxacara mystax (Zeder, 1800) (HWML 66666) was found in the intestine of a male from Guadalupe County (2 specimens) and female from Harding Count (13 specimens). The current paper is the first report of T. mystax from gray foxes.

\section{Spirocerca Railliet and Henry, 1911}

Spirocerca lupi (Rudolphi, 1899) was recovered from 6 foxes (42.9\%), a female from Harding (37 intact specimens and 28 pieces), a female from Lea (1 intact specimen), a male from Quay (1 specimen), a female from San Juan (4 specimens), a female from Colfax (2 specimens), and a male from Catron (3 specimens) counties. Conti (1984) reported it in $12 \%$ of gray foxes in Florida. Buechner (1944) found only a single worm in gray foxes from Texas and indicated that it was not an important parasite of the gray fox in Texas. It was also reported by 
Erickson (1944) from Minnesota. Buechner (1944) examined 80 gray foxes from Harrison Co. eastern Texas and Kerr and Mason counties from central Texas and reported S. lupi. Forrester (1992) reported S. lupi from gray foxes in Florida. Ubelaker et al. (2013) found it in red foxes, $V$. vulpes from New Mexico.

Other nematodes from gray foxes but not found in our study include: Dracunculus insignis (Leidy, 1858) from the southeastern US by Davidson et al. (1992a), Ancylostoma caninum (Erocolani, 1859), Ancylostomidae, and Uncinaria Froelich, 1789 (sp.) by Stiles and Baker (1935), A. caninum, Capillaria Zeder, 1800 (sp.), Molineus Cameron, 1932 (sp.), and Uncinaria stenocephala (Railliet, 1884) by Davidson et al (1992). Uncinaria stenocephala was also reported from Massachusetts by Rankin (1946). Dirofilaria immitis (Leidy, 1856) has been reported from Southern Illinois by Dyer and Klimstra (1982), from North Carolina and South Carolina by Miller and Harkema (1968), from New York by Stone (1974) and Monson et al. (1973), from Louisiana by Crowell et al. (1977), from Indiana by Kazacos (1977) and Kazacos and Edberg (1979), from Michigan by Stuht (1978), from Alabama, Georgia, and Mississippi by Simmons et al. (1980), from Florida by Conti (1984), and from North and South Carolina and Georgia by Miller and Harkema (1968). MacGregor (1942) found nematodes in 12 of 13 gray foxes from Massachusetts and eggs in one gray fox dropping (scat) from MacGregor's study, these nematodes were identified by Dr. J. F. Mueller of the New York State College of Forestry as Toxascaris (limbata?) = leonina (Linstow, 1902) and Physaloptera Rudolphi, 1819 (sp.). Erickson (1944) reported A. braziliense Gomez de Faria, 1910, and A. caninum from Minnesota. Capillaria aerophila (Crepelin, 1839), Crenosoma vulpis (Dujardin, 1845), Haemonchis similis Travassos, 1914, Uncinaria sp., Toxascaris leonina, and Dracunuclus insignis (Leidy, 1858) were reported from Georgia by Davidson et al (1992a). Davidson et al. (1992) also reported Capillaria (sp.), A. caninum, Molineus sp., Toxascaris sp., Toxocara sp., and Uncinaria stenocephala. Molineus barbatus Chandler, 1942, A. tubaeforme, Trichuris vulpis (Froelich, 1789), and the larvae of an unidentified spiurid, Capillaria aerophila (Crepelin, 1839) and Strongyloides stercoralis (Bavay, 1876) was reported from Florida by Conti (1984). Ancylostoma caninum, Toxascaris leonina, and Trichuris vulpis were reported from Southern Illinois by Dyer and Klimstra (1982). Forrester (1992) summarized the helminths reported from 26 gray foxes in Florida [including the study by Conti (1984)] and reported these nematodes Molineus barbatus (Chandler, 1942), $A$. tubaeforme, A. caninum, A. braziliense, T. vulpis, spiurid larvae, D. immitis, C. aerophila and S. stercoralis. Miller and Harkema (1968) reported Molineus patens (Dujardin, 1845), A. caninum, C. aerophila, C. plica (Rudolphi, 1819), and T. vulpis from gray foxes in North Carolina, South Carolina, and Georgia. Goble and Cook (1941) examined 12 gray foxes from New York State and reported Crenosoma vulpis (Dujardin, 1845) from 2 of them. According to Erickson (1944), Goble reported to him in 1942 that the examination of 88 gray foxes from New York State revealed $15-17 \%$ infected by Crenosoma vulpis and 6-7\% infected by Capillaria aerophila. Buechner (1944) examined 80 gray foxes from Harrison Co. eastern Texas and Kerr and Mason counties from central Texas. In addition to records listed above he reported the nematodes $A$. caninum, A. braziliense, $H$. similis, and Eucoleus aerophilus (syn. C. aerophila). Conti (1984) reported these parasites from gray foxes in Florida: Molineus barbatus, $A$. tubaeforme (Zeder, 1800), Trichuris vulpis, spiruid larvae, Capillaria aerophila, A. caninum, A. braziliense and Strongyloides stercoralis.

Although we did not find Acanthocephala in New Mexico, thorny-headed worms have been reported previously from gray foxes. Erickson (1944) reported Pachysentis canicola Meyer, 1931 in gray foxes from Minnesota. Buechner (1944) also reported this acanthocephalan from Texas. Conti (1984) reported an unidentified acanthocephalan in addition to Centrorhychus wardae Holloway, 1958, P. canicola, and Moniliformis moniliformis (Bremser, 1811) from Florida. Forrester (1992) reported C. wardae, P. canicola, M. moniliformis and immature forms of either Oncicola Travassos, 1916 (sp.) or Macracanthorhynchus Travassos, 1917 (spp.) from Florida.

\section{Discussion}

Gastrointestinal parasites in wild canid populations have been studied in North America (Erickson, 1944, Samuel et al., 1978 and references therein). Chaddock (1939) evaluated the food habits of foxes in Wisconsin and noted that in 61 of 113 gray fox stomachs (52\%), nematodes were found. Our findings show a much reduced parasitic fauna in gray foxes in New Mexico which may be a response to the arid region from where the foxes were collected. Three new parasites are reported here for the first time in gray foxes, including: Fasciola hepatica, Toxacara cati and an unidentified pentastome. The largest number of parasites recovered was Mesocestoides kirbyi with a total of 555 scolexes from 7 animals with 1 host containing 245 scolexes. Spirocerca lupi was the second most prevalent parasite with 48 intact specimens and numerous pieces recovered from 6 animals. Toxocara 
mystax was present in 2 animals totaling 15 specimens. The remaining 7 parasites occurred in smaller numbers with five specimens or less of each parasite within the foxes. The parasite fauna in the gray fox argues strongly for a broad prey base.

Acknowledgments - We thank J. L. Dunnum and S. V. Brant for assistance in the deposition and curation of foxes and their worms at UNM. We thank S. L. Gardner and G. R. Rácz for deposition of Pentastomida, Fasciola hepatica and Toxacara cati and a slide of Mesocestoides kirbyi in the H.W. Manter Laboratory of Parasitology, Parasite Collection, University of Nebraska State Museum, Lincoln, Nebraska and for confirming identifications of these species.

\section{Literature Cited}

Buechner, H. K. 1944. Helminth parasites of the gray fox. Journal of Mammalogy 25: 185-188.

Chaddock, T. T. 1939. Report on gray and red fox stomach examinations. Wisconsin Conservation Bulletin 4: 53-54.

Chandler, A. C. 1941 Mesocestoides manteri n. sp. from a lynx, with notes on other North American species of Mesocestoides. Journal of Parasitology 28:227-231.

Chandler, A. C. 1942. First case of human infection with Mesocestoides. Science 96: 112.

Chandler, A. C. 1944. A new species of Mesocestoides, M. Kirbyi, from Canis latrans. The Journal of Parasitology 30: 273.

Chitwood, B. G. 1931. Physaloptera praeputialis from Urocyon sp., in Virginia and Lynx rufus, Nevada. The Journal of Parasitology 18: 53.

Ciordia, H. 1955. Mesocestoides jonesi, n. sp., from the gray fox, with descriptions of the chromosome complement and a dicephalic specimen. Journal of the Tennessee Academy of Sciences 30: 57-63.

Conti, J. A. 1984. Heminths of foxes and coyotes in Florida. Proceedings of the Helminthological Society of Washington 51: 365-367.

Crowell, W. A., T. R. Klei, D. I. Hall, N. K. Smith and J. D. Newsom. 1977. Occurrence of Dirofilaria immitis and associated pathology in coyotes and foxes from Louisiana. In: H. C. Morgan, G. F. Otto, R. F. Jackson and C. H. Courtney (eds.). Proc. Heartworm Symposium 77, p. 10-13.

Davidson, W. R., M. J. Appel, G. L. Doster, O. E. Baker, and J. F. Brown. 1992. Diseases and parasites of red foxes, gray foxes, and coyotes from commercial sources selling to fox-chasing enclosures. Journal of Wildlife Diseases 28: 581-589.

Davidson, W. R. , V. F. Nettles, L. E. Hayes, E. W. Howerth, and C. E. Couvillion. 1992a. Diseases diagnosed in gray foxes (Urocyon cinereoargenteus) from the southeastern United States. Journal of Wildlife Diseases 28: 28-33.
Dyer, W. G. and Klimstra W. D. 1982. Gastrointestinal helminths in gray foxes (Urocyon cinereoargenteus) of southern Illinois. Transactions of the Illinois Academy of Sciences 75: 289-295.

Dyer, W. G. and Klimstra, W. D. 1982a. Pancreatic flukes (Eurytrema procyonis) in red and gray foxes from southern IIlinois. Transactions of the Illinois Academy of Science 75: 121-123.

Erickson, A. B. 1944. Helminths of Minnesota Canidae in relation to food habits, and a host list and key to the species reported from North America. American Midland Naturalist 32: 358-372.

Esslinger, J. H. 1962. Development of Porocephalus crotali (Humbolt, 1808) (Pentastomida) in experimental intermediate hosts. The Journal of Parasitology 48: 452-456

Findley, J. S., A. H. Harris, D. E. Wilson, and C. Jones. 1975. Mammals of New Mexico. University of New Mexico Press, Albuquerque.

Forrester, D. J. 1992. Chapter 16. Foxes and Coyotes, pp 204217 In: Parasites and Diseases of Wild Mammals in Florida. The University Press of Florida 459 pp.

Goble, F. C. and A. H. Cook. 1941. Some lungworm records from foxes in New York. Journal of Mammalogy 22: 456.

Hall, M. C. 1919. The adult taenioid cestodes of dogs and cats, and of related carnivores in North America. Proceedings of the U. S. National Museum 55: 1-94.

Harrison, R. L., M. J. Patrick, and C. G. Schmitt. 2003. Foxes, fleas, and plague in New Mexico. The Southwestern Naturalist 48: 720-722.

Herman, C. M., P. M. Bauman, and R. R. Habermann. 1957. The prevalence of Eurytrema procyonis Denton (Trematoda:Dicrocoeliidae) in some mammals from Maryland. The Journal of Parasitology 43: 113-114.

Kazacos, K. R. 1977. Dirofilaria immitis in wild canidae from Indiana. Proceedings of the Helminthological Society of Washington 44: 233- 234.

Kazacos, K. R. and E. Q. Edberg. 1979. Dirofilaria immitis infection in foxes and coyotes in Indiana. Journal American Veterinary Medical Association 175: 909-910.

Layne, J. N. 1967. Incidence of Porocephalus crotali (Pentastomida) in Florida mammals. Journal of Wildlife Diseases 3: 105-109.

MacGregor, A. E. 1942. Late fall and winter food of foxes in central Massachusetts. Journal of Wildlife Management 6: 221-224.

Miller, G. C. and R. Harkema. 1968. Heminths of some wild mammals in the southeastern United States. Proceedings of the Helminthological Society of Washington 35: 118-125.

Monson, R. A., W. B. Stone, and B. C. Weber. 1973. Heartworms and microfilaria in a gray fox. New York Fish and Game Journal 20: 48-53.

Mueller, J. 1927. Two new species of the cestode genus Mesocestoides. Transactions of the American Microscopical Society 46: 294. 
Morgan, B. B. 1941. A summary of the Physalopterinae (Nematoda) of North America. Proceedings of the Helminthological Society of Washington 8: 28-30.

Olsen, O. W. 1948. Wild rabbits as reservoir hosts of the common liver fluke, Fasciola hepatica, in southern Texas. The Journal of Parasitology 34: 119-123.

Olsen O. W. 1974. Animal parasites. Their life cycles and ecology. University Park Press, Baltimore, London and Tokyo pp. 455-458.

Rankin Jr., J. S. 1946. Helminth parasites of birds and mammals in Western Massachusetts. American Midland Naturalist 35: 756-768.

Riley, J. 1981. An experimental investigation of the development of Porocephalus crotali (Pentastomida: Porocephalida) in the western diamondback rattlesnake (Crotalus atrox). International Journal of Parasitology 11: 127-132.

Samuel, W. M., Ramalingam, S. and Carbyn L. N. 1978. Helminths in coyotes (Canis latrans Say), wolves (Canis lupus L.) and red foxes (Vulpes vulpes L.) of southwestern Manitoba. Canadian Journal of Zoology 56: 2614-2617.

Schmidt, G. D. 1986. CRC Handbook of tapeworm identification. CRC Press, Boca Raton, florida 675 pp..

Shults, L. M. 1970. Mesocestoides kirbyi and M. lineatus: occurrence in Alaskan carnivores. Transactions of the American Microscopical Society 89: 478-486.

Simmons, J. M., W. S. Nicholson, E. P Hill, and D. B. Briggs. 1980. Occurrence of (Dirofilaria immitis) in gray fox (Urocyon cinereargenteus) in Alabama and Georgia. Journal of Wildlife Diseases 16: 225-228.
Stiles, C. W. and C. E. Baker. 1935. Key-catalogue of parasites reported from Carnivora (cats, dogs, bears, etc.) with their possible public health Importance. National Institute of Health Bulletin (163) U. S. Public. Health Service, Dec. 1934, pp 913-1223.

Stone, W. B. 1974. Heartworms and microfilaria in a gray fox. New York Fish and Game Journal 21: 87.

Stuht, J. H. 1978. Dirofilariasis in a gray fox. Michigan Department Natural Resources Wildlife Division Report No. 2821.

Ubelaker, J.E., B. S. Griffin, D. W. Duszynski and R. L. Harrison. 2013. Distribution records for helminths of the red fox Vulpes vulpes from New Mexico. Southwestern Naturalist 58: 111-112

Ubelaker, J.E., B. S. Griffin, G. M. Konicke, D. W. Duszynski, and R. L. Harrison 2014. Helminth parasities from the kit fox, Vulpes macrotis (Carnivora: Canidae) from New Mexico. Comparative Parasitology 81: 100-104.

Ubelaker, J. E., B. S. Griffin, G. M. Konicke, D. W. Duszynski, and R. L Harrison 2014a. Distributional records of helminths of the swift fox Vulpes velox from New Mexico. The Southwestern Naturalist 59: 129-132.

Ulmer, M. J. 1975. Other trematode diseases. Pages 646-677. In: Diseases transmitted from Animals to Man, $6^{\text {th }}$ ed. Ed. by Hubbert, W.T., McCulloch, W.F. and Schnurrenberger, P.R. Charles C. Thomas. 1206 pp.

Voge, M. 1953. New host records for Mesocestoides (Cestoda: Cyclophyllidea) in California. The American Midland Naturalist 49: 249-251.

Ward, J. W. 1947. Studies on parasites and food habits of foxes. Journal of Parasitology 33: (suppl. 6, sect. 2), 23-24. 